\title{
QUALITY OF DRYING SUNFLOWER CROP AFTER MECHANICAL THRESHING
}

\author{
Hamada El-Khateeb* Husain Sorour** \\ Mohmed Khodeir* Mohmed Saad*
}

\begin{abstract}
Results indicated that:

The maximum values of the germination ratio were of about $95.1 \%$ and $90.03 \%$ for the Corn Sheller and El-Shams threshing machines, respectively, at a minimum airflow temperature of about $313 \mathrm{~K}\left(40^{\circ} \mathrm{C}\right)$, highest level of feeding rate $(10 \mathrm{~kg} / \mathrm{min})$ and lowest level of moisture content (11.32\%).
\end{abstract}

The optimum condition for drying process are at air temperature of 333 ${ }^{\circ} \mathrm{K}$ and sunflower heads moisture content of $17.07 \%$.

\section{INTRODUCTION}

unflower is an important oil crop in the world. It ranks the second after soybeans with respect to oil production in the world (Yearbook of Agric. FAO, 1990). In Egypt, 1,129000 Mg of oils is consumed annually but until now we produce only $153,000 \mathrm{Mg}$. This means that we produce only about $13.55 \%$ of all our needs and import about $86.45 \%$ (976,000 Mg). (oilseed situation and outlook 2002).

While, the problem of sunflower seeds drying could be explained as follows: harvesting sunflower with high moisture content normally results in higher yields, less bird damage and less head dropping and shattering. Under certain fall conditions, drying may become mandatory, so harvesting can be completed. Many producers who dry sunflowers will experience a fire until they learn proper drying procedures. However, generally the conditions are favorable in Egypt for field drying of sunflower without artificially drying.

The main purpose of this study is to evaluate the drying sunflower seeds losses after mechanical threshing as a suggestion solution for increasing the production of sunflower seeds in Egypt.

* Researcher, in Agric. Eng. Res. Inst., Dokki- Giza., Egypt. ** Prof. of Agric. Eng. Fac. of Agr. Kafr El-Sheikh Univ. 
Michael and Ojha (1978) revealed that, drying is the universal method of conditioning grain by removing moisture to moisture content level that is in equilibrium with normal atmospheric air in order to preserve its quality and nutritive value as a food and its viability for seeds. Also, they reported that there are three methods of drying grain with the use of air. (a) unheated or natural air-drying; (b) unheated air drying with supplemental heat; and (c) heated air-drying.

Brooker et al. (1978) stated that, several parameters influence the time required to reduce the product to the desired moisture content for a particular grain. These include air temperature, air relative humidity, airflow, original moisture content, and final moisture content. These parameters are considered in the design of the equipment and are manipulated in its operation to dry the grain within the time limit selected. Also, they mentioned that the operator better controls drying operations when heated air is used for drying.

Li and Morey (1984) developed an equation to determine thin - layer drying rates for yellow dent corn as affected by drying air temperature, air flow rate, initial moisture content, and relative humidity. They found that, drying air temperature had the greatest effect on drying rates. Initial moisture content also influenced drying rates. Air flow and relative humidity had smaller effects.

Harner (1987) found that, drying temperatures of 160 up to 220 degrees $F$ ( 71-104 $\mathrm{C}^{\mathrm{o}}$ ) do not have an adverse effect on oil yield or fatty acid composition of sunflower seeds with the non-oil varieties, high drying temperatures may cause the nutmeats (kernels) to be steamed, wrinkled or even scorched. Continuous-flow dryers and recalculating-batch dryers should be operated at plenum temperatures of 160 degrees F. Batch and bin dryers should be operated at 110 to 140 degrees $\mathrm{F}\left(43-60 \mathrm{C}^{\circ}\right)$, respectively. under no conditions should sunflowers to be used for seed be dried at plenum temperatures over 110 degrees $F$.

Li et al. (1987) tested the effect of oil content on thin - layer drying rate and verify and modify Syariefs model using four different varieties, three drying temperatures and two initial moisture contents. They revealed that 
the oil content has no significant effect on drying rates of sunflower seeds. The effect of initial moisture content on drying rates at the drying air temperature of $333 \mathrm{~K}\left(60{ }^{\circ} \mathrm{C}\right)$ is not large, but should be considered at higher or lower drying temperatures.

Saskatchewan (1993) reported that, sunflowers may be harvested at high moisture contents to reduce loss from bird damage, head shattering and poor weather. They must then be dried to a moisture content of $8-10 \%$ with dryers or aeration.

Grady (2004) reported that, harvesting sunflower at moisture contents as high as $25 \%$ may reduce bird damage and seed shattering loss during harvest. Seed must then be dried to $9.5 \%$ moisture or less for storage.

MAF.(2004) found that, sunflower seed is safe to store at a moisture content of nine and a half percent or less. At 10 to 12 percent moisture content seed can be stored in bins with aeration. Any moisture content over 12 percent will required drying. Oil-type sunflower can be dried with temperatures of 71-104 $\mathrm{C}^{\mathrm{o}}$ (160-220 degrees F) but confection types may scorch or wrinkle with these temperatures.

Warrick (2004) reported that, oil sunflower should not be stored above 10 percent moisture during the winter and 8 percent during the summer. Non oilseed sunflower should not be stored above 11 percent moisture during the winter and 10 percent during the summer. Sunflower can be stored for short periods at 12 percent with adequate airflow to keep the seeds cool. Resistance of oilseed sunflower to fungal infection during storage at 10 percent moisture is equal to wheat resistance at 17 percent stored moisture.

\section{MATERIALS AND METHODS}

Experiments were carried out at the research farm of Rice Mechanization Center, Meet El-Dyba, Kafr El-Sheikh Governorate, during season 2006 to evaluate the drying sunflower seeds losses after mechanical threshing as a suggestion solution for increasing the production of sunflower seeds in Egypt. The specification of threshing machines as shown in Table 1. 
Table 1: Specifications of threshing machines.

\begin{tabular}{|c|c|c|}
\hline Items & El-Shams & Corn Sheller \\
\hline - length, width and height, cm & 400,220 and 240 & 225,110 and 165 \\
\hline - mass, kg & 1550 & 750 \\
\hline - source of power & \multicolumn{2}{|c|}{ Tractor's pulley flat belt } \\
\hline - type of the cylinder & spike tooth & spike tooth \\
\hline $\begin{array}{l}\text { - length and diameter of the } \\
\text { cylinder, } \mathrm{cm}\end{array}$ & 120 and 70 & 95 and 25 \\
\hline - input opening for crop, cm & $120 \times 40$ & $65 \times 40$ \\
\hline $\begin{array}{l}\text { - output opening for straw and } \\
\text { grain, cm }\end{array}$ & $59 \times 35$ and $10 \times 10$ & $25 \times 45$ and $15 \times 13$ \\
\hline
\end{tabular}

\section{Sunflower heads and seeds physical properties.}

The average physical properties and characteristics of the sunflower plants, heads and seed are summarized in Tables 2 and 3.

Table2:Same physical properties of sunflower plants, heads and seeds of variety vidok.

\begin{tabular}{|c|c|c|c|c|c|c|c|}
\hline $\begin{array}{c}\text { Variety } \\
\text { name }\end{array}$ & $\begin{array}{c}\text { Plant } \\
\text { height, } \\
\mathrm{cm}\end{array}$ & $\begin{array}{c}\text { Head } \\
\text { diameter, } \\
\mathrm{cm}\end{array}$ & $\begin{array}{c}\text { Stem } \\
\text { diameter, } \\
\mathrm{cm}\end{array}$ & $\begin{array}{c}\text { seed } \\
\text { yield/plant, } \\
\mathrm{g}\end{array}$ & $\begin{array}{c}\text { Mass of } \\
\mathbf{1 0 0 0} \\
\text { seeds, } \mathrm{g}\end{array}$ & $\begin{array}{c}\text { Seed } \\
\text { length } \\
\text { mm }\end{array}$ & $\begin{array}{c}\text { Seed } \\
\text { Width } \\
\mathrm{mm}\end{array}$ \\
\hline vidok & 169.86 & 21.4 & 27 & 17050 & $\mathbf{8 3 5}$ & 12.68 & 5.00 \\
\hline
\end{tabular}

Table 3: Same physical properties of sunflower variety vidok.

\begin{tabular}{|c|c|}
\hline Characteristics & Dimensions \\
\hline \multicolumn{2}{|l|}{ Seeds: } \\
\hline - length, mm & $9.67-13.93$ \\
\hline - $\quad$ width, mm & 3.31-6.4 \\
\hline - $\quad$ thickness, mm & $2.10-5.58$ \\
\hline mass, $\mathbf{g}$ & 0.04- 0.0.12 \\
\hline - $\quad$ moisture content, \% & $5.00-15.00$ \\
\hline - $\quad$ bulk density, g/cm2 & 44.97 \\
\hline \multicolumn{2}{|l|}{$\underline{\text { Heads }}$} \\
\hline diameter, $\mathbf{m m}$ & 214 \\
\hline number of seeds. & $15-28$ \\
\hline - $\quad$ mass of 100 Seeds, $g$ & 8.11 \\
\hline moisture content, $\%$ & $12.00-35.00$ \\
\hline
\end{tabular}

\section{Draying stage.}

The experiments were mainly carried out to determine the effect of variables such as the moisture content and air temperature at constant 
airflow rate on the quality of sunflower (losses of sunflower during drying process).

To meet with the objectives of the present study, an airflow drying system was manufactured. The system consists of three bins, with a circular cross section area, constructed and installed at Rice Mechanization Center (RMC), Meet El - Deeba, Kafr El - Sheikh Governorate Agric. Eng. Res. Instate. The system was termed as electrical -heated forced air- drying system. The air was heated by a heater prior to be forcing through the seeds by a centrifugal fan.

\section{Experimental test apparatus:}

Three separate cylindrical seed bins, each holding $0.07547 \mathrm{~m}^{3}$ of sunflower seeds, were constructed of $1.5 \mathrm{~mm}$ galvanized sheet metal with $1 \mathrm{~m}$ height and $0.31 \mathrm{~m}$ inside diameter. A steel screen supported by crossshape steel bars was fixed in the seed column at a distance of $0.2 \mathrm{~m}$ from the bottom to carry the sunflower. Each column rested on an air plenum chamber, to maintain uniform velocity inside the seed bulk. It was constructed of $1.5 \mathrm{~mm}$ galvanized sheet metal with an inside cross sectional diameter of $0.31 \mathrm{~m}$ and $0.2 \mathrm{~m}$ high. These three bins were merely designed to represent a small scale of a drying structure. Figure 1 shows the general view of drying system showing the main components.

This drying and aeration system provide the same air path distance from the duct to the outer surface of the seed throughout the bin. The method of air distribution (ducting system) consisted of a centrifugal fan, an air velocity gate, and a hand - operated valve. Moreover, plastic pipes and flexible tubing were contained in this system to maintain the uniform distribution of air through them. Centrifugal fan connected with electric motors were used to force air through the seed test column. The electrical motor power was $0.25 \mathrm{~kW}$. The airflow was changed by control air valve by measuring air velocity in the plastic pipe itself at the entrance of the seed column. 


\section{Cylindrical seed bins}

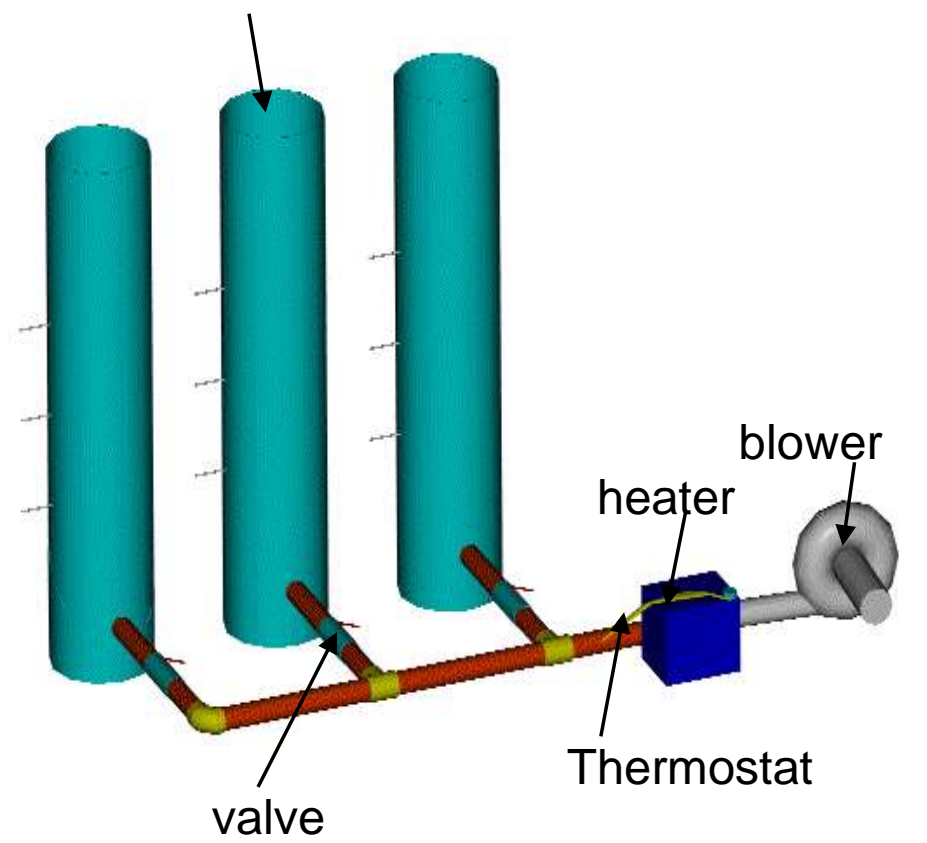

Fig.1: The general view of forcing drying system

\section{Drying variables.}

To realize the objective of the drying stage. The experiments were conducted under the following variables:-

1-Two different threshing machines namely El-Shams thresher and Corn Sheller.

2-Three different moisture content for sunflower heads 11.32, 17.07 and $22.29 \%$ (w.b) ( same moisture content at harvesting time )

3-Three different temperature namely,313, 323 and $333^{\circ} \mathrm{K}\left(40,50\right.$ and $\left.60^{\circ} \mathrm{C}\right)$ Through drying process of sunflower seeds, the airflow rate in drying system was adjusted at $318.88\left(\mathrm{~m}^{3} / \mathrm{h} \cdot \mathrm{m}^{2}\right)$

\section{Measurements and instrumentation:}

\section{Airflow measurement:}

Using an anemometer Vane Probe - BREMI - BRI 5080 did the measurement of air velocity. The unit is a self - contained direct reading 
portable instrument, which is capable for measuring velocities from 0.2 to $40.0 \mathrm{~m} / \mathrm{s}$ its accuracy is $0.1 \mathrm{~m} / \mathrm{s}$.

The quantity of airflow was determined by multiplying the average velocity by the cross - sectional area of the air distribution pipe. However, it was necessary to obtain the velocity for long time and an average was obtained. Hence, air velocity was measured directly before the entrance of the grain column. The commonly accepted measuring unit of the rate of airflow in this field is cubic meter per hour per square meter of cross sectional area for seed column $\left(\mathrm{m}^{3} / \mathrm{h} . \mathrm{m}^{2}\right)$.

\section{Mass measurement:}

The mass of the samples was determined by using a digital balance (Yamata, Laptop balance LY-200) with an accuracy of 0.01g.For determining the bulk mass density and the grain moisture content through the mass of the wet and dry sample.

\section{Bulk density measurements.}

To calculate in - bin bulk density from the total mass and volume of the seed in the test column, a calibrated scale was used for this purpose. The scale arm had a $10 \mathrm{~kg}$ with an accuracy of $5 \mathrm{~g}$.

\section{Moisture content determinations:}

Moisture content of sunflower samples was determined on a wet - mass basis by moisture tester PV-100. The apparatus was calibrated by oven drying duplicate samples at $378{ }^{\circ} \mathrm{K}\left(105{ }^{\circ} \mathrm{C}\right)$ for $24 \mathrm{~h}$, as presented in ASAE (1998). Aluminum cylinders contain of about $50 \mathrm{~cm}^{3}$ of seed samples were used.

\section{Temperature measurements:}

A temperature meter model (ERO, Electronic. Memocal ${ }^{R}$ 81) was connected to an iron - Constantine thermocouple type $(\mathrm{T})$ to measure air and grain temperatures for the drying systems. The urgent measuring check points for the drying systems were in the air passing through the ducting system (just before the entrance of the grain columns).

\section{Seed viability:}

The viability of seeds are defined as the ability of the seed to develop into a young plant (i.e., to germinate) under favorable condition in the absence 
of dormancy. The International Seed Testing Authority (ISTA, 1985) germination test consists of placing 4 x 100 seeds between wet paper or in wet sand at $288-303 \mathrm{~K}\left(15-30{ }^{\circ} \mathrm{C}\right)$ for 7 day. Table 3 shows the germination of seed for forcing air method of sunflower seeds.

\section{Drying losses measurements:}

The drying losses were affected by the drying temperature and couldn't germinated after drying process. To measure this type of losses three samples (100 seeds each) of sunflower seeds were taken before and after drying process to calculate the germination ratio in the laboratory for each drying treatment. The germination ratio was calculated for sunflower seeds before and after drying process for each treatment under study. The difference between values of germination ratio before and after drying process was taken as the draying losses.

\section{RESULTS AND DISCUSSION}

Figures (2), (3) and Table (4) indicate the change in seed germination ratio related to threshing machines, feeding rates, moisture contents of sunflower seeds and air temperature at $400 \mathrm{rpm}$ drum speed. The results showed that, the germination ratio decreased with increasing the air temperature for the two threshing machines (El-Shams and Corn Sheller), due to the bad effect of high airflow temperatures on the kernel and embryo.

Also, these Figures indicated that the germination ratio decreased with increasing the moisture content, due to increase drying time, which exposed the seeds to air temperature (heat) for a long period. Also, the germination ratio decreased by decreasing the feeding rate for both type of threshing machines. these results may be due to the damage occurs for the seeds during the threshing process at low feeding rates which affected on the germination ratio, at the three levels of air temperatures and moisture contents. Meanwhile the germination ratio decreased generally in the threshing machine El- Shams than corn Sheller during drying process. This is due to the effect of threshing process which increase the damage percentage in El- Shams than Corn Sheller, consequently affected on dried sunflower seeds. 
The maximum values of the germination ratio were of about $95.1 \%$ and $90.03 \%$ for the Corn Sheller and El- Shams threshing machines, respectively, at a minimum airflow temperature of about $313 \mathrm{~K}\left(40{ }^{\circ} \mathrm{C}\right)$, highest level of feeding rate $(10 \mathrm{~kg} / \mathrm{min})$ and lowest level of moisture content $(11.32 \%)$. However the minimum values of the germination ratio were of about $51.35 \%$ and $42.14 \%$ for the Corn Sheller and El- Shams threshing machines, respectively, were obtained at the maximum airflow temperature of about $333 \mathrm{~K}\left(60{ }^{\circ} \mathrm{C}\right)$, lowest level of feeding rate 2.5 $\mathrm{kg} / \mathrm{min}$ and a highest level of moisture content of $22.29 \%$ (w.b.).

Table4:Germination ratio before and after drying process for two machines under different feed rate, moisture content and air temperature at $\mathbf{4 0 0} \mathrm{rpm}$ drum speed.

\begin{tabular}{|c|c|c|c|c|c|c|c|c|c|}
\hline \multicolumn{2}{|c|}{ Items } & \multicolumn{4}{|c|}{ EL-Shams Thresher } & \multicolumn{4}{|c|}{ Corn Sheller } \\
\hline \multirow{2}{*}{$\begin{array}{l}\text { Feeding } \\
\text { rate, } \\
\text { Kg/min }\end{array}$} & \multirow{2}{*}{$\begin{array}{c}\text { Moisture } \\
\text { content, } \\
\%\end{array}$} & \multirow[b]{2}{*}{$\begin{array}{l}\text { Before } \\
\text { drying }\end{array}$} & \multicolumn{3}{|c|}{ Air temperature, } & \multirow{2}{*}{$\begin{array}{l}\text { Before } \\
\text { drying }\end{array}$} & \multicolumn{3}{|c|}{ Air temperature, } \\
\hline & & & $\begin{array}{c}40 \\
313\end{array}$ & $\begin{array}{c}50 \\
323\end{array}$ & $\begin{array}{c}60 \mathrm{C}^{0} \\
333 \mathrm{~K}^{0}\end{array}$ & & $\begin{array}{c}40 \\
313\end{array}$ & \begin{tabular}{|c|}
50 \\
323
\end{tabular} & $\begin{array}{l}60 \mathrm{C}^{0} \\
333 \mathrm{~K}^{0}\end{array}$ \\
\hline \multirow{3}{*}{2.5} & 11.32 & 80.54 & 72.41 & 67.96 & 63.51 & 86.10 & 81.32 & 73.80 & 68.03 \\
\hline & 17.07 & 75.02 & 69.75 & 61.31 & 59.52 & 84.16 & 79.30 & 73.10 & 65.90 \\
\hline & 22.29 & 72.58 & 66.49 & 59.00 & 42.14 & 81.24 & 76.36 & 70.27 & 51.35 \\
\hline \multirow{3}{*}{5} & 11.32 & 84.80 & 78.00 & 72.58 & 68.65 & 93.16 & 88.90 & 82.54 & 75.98 \\
\hline & 17.07 & 81.76 & 76.50 & 70.32 & 63.80 & 91.40 & 86.50 & 79.65 & 71.71 \\
\hline & 22.29 & 79.56 & 74.56 & 68.31 & 60.13 & 88.46 & 83.90 & 75.10 & 67.20 \\
\hline \multirow{3}{*}{7.5} & 11.32 & 90.40 & 83.62 & 78.11 & 71.74 & 95.30 & 90.27 & 83.20 & 79.90 \\
\hline & 17.07 & 87.16 & 82.99 & 75.33 & 67.80 & 93.76 & 87.06 & 80.54 & 75.24 \\
\hline & 22.29 & 84.38 & 79.82 & 72.30 & 63.57 & 89.84 & 80.94 & 75.24 & 69.15 \\
\hline \multirow{3}{*}{10} & 11.32 & 93.96 & 90.03 & 86.25 & 79.50 & 98.54 & 95.10 & 90.40 & 82.50 \\
\hline & 17.07 & 91.54 & 89.20 & 81.10 & 74.45 & 96.64 & 90.00 & 84.95 & 75.60 \\
\hline & 22.29 & 87.52 & 83.70 & 76.00 & 70.20 & 91.34 & 84.00 & 79.30 & 69.00 \\
\hline
\end{tabular}

\section{Total drying cost (LE./Mg).}

Table (5) summarized the total drying and threshing losses cost for two different threshing machines under sunflower moisture contents of 11.32, 17.07 and $22.29 \%$ and drying air temperature of about 313, 323 and 333 $\mathrm{k}^{\mathrm{o}}$, at threshing drum speed of $400 \mathrm{rpm}$ and feeding rate of $7.5 \mathrm{~kg} / \mathrm{min}$. From this Table it could be concluded that increasing moisture contents of sunflower seeds decreased the drying cost and threshing losses cost. Also, increasing air temperature decreased the drying cost under different sunflower seed moisture contents at drum speed of $400 \mathrm{rpm}$ and feeding rate of $7.5 \mathrm{~kg} / \mathrm{min}$. By adding the threshing losses due to threshing the sunflower seeds on higher moisture content to the drying cost. One can say, the drying cost of the sunflower seeds decreased by increasing drying 
air temperature and increased by increasing sunflower seeds moisture content. These results means that, the sunflower seeds moisture content of $17.07 \%$ is consider the optimum moisture content for threshing and drying sunflower seeds at any given drying air temperature due to obtained the lowest total threshing losses/drying cost when taken the natural scattering of seeds under consideration due to threshed sunflower seeds at seeds moisture content of $11.32 \%$ or lees in addition to the birds eating losses.

Table (5): Effect of drying air temperature on total drying cost under different sunflower head moisture contents at drum speed of $400 \mathrm{rpm}$ and feeding rate of $7.5 \mathrm{~kg} / \mathrm{min}$. for both type of threshing machines.

\begin{tabular}{|c|c|c|c|c|c|c|c|c|}
\hline \multirow{2}{*}{$\begin{array}{c}\text { Thresh } \\
\text { machine }\end{array}$} & \multirow{2}{*}{$\begin{array}{c}\text { Moisture } \\
\text { content, \% }\end{array}$} & \multicolumn{3}{|c|}{ Drying cost, LE/Mg. } & \multirow{2}{*}{$\begin{array}{c}\text { Losses } \\
\text { cost, } \\
\text { L.E./Mg. } \\
\end{array}$} & \multicolumn{3}{|c|}{ Total drying cost, L.E./Mg } \\
\hline & & 313 & 323 & $333 \mathrm{~K}^{0}$ & & 313 & 323 & $333 \mathrm{~K}^{0}$ \\
\hline \multirow{3}{*}{ El-Shams } & 11.32 & 8 & 6.79 & 4.92 & 74.085 & 81.47 & 80.88 & 79. \\
\hline & 17.07 & 9.25 & 8.44 & 6.92 & 102.23 & 111.48 & 110.67 & 109.15 \\
\hline & 22.29 & 17.93 & 10.55 & 7.62 & 120.65 & 138.58 & 131.20 & 128.27 \\
\hline \multirow{3}{*}{$\begin{array}{c}\text { Corn } \\
\text { Sheller }\end{array}$} & 11.02 & 7.38 & 6.79 & 4.32 & 39.31 & 46.69 & 46.10 & 44.25 \\
\hline & 17.07 & 9.25 & 8.44 & 6.92 & 70.21 & 79.46 & 78.65 & 77.13 \\
\hline & 22.29 & 17.93 & 10.55 & 7.62 & 93.58 & 111.51 & 104.23 & 101.2 \\
\hline
\end{tabular}

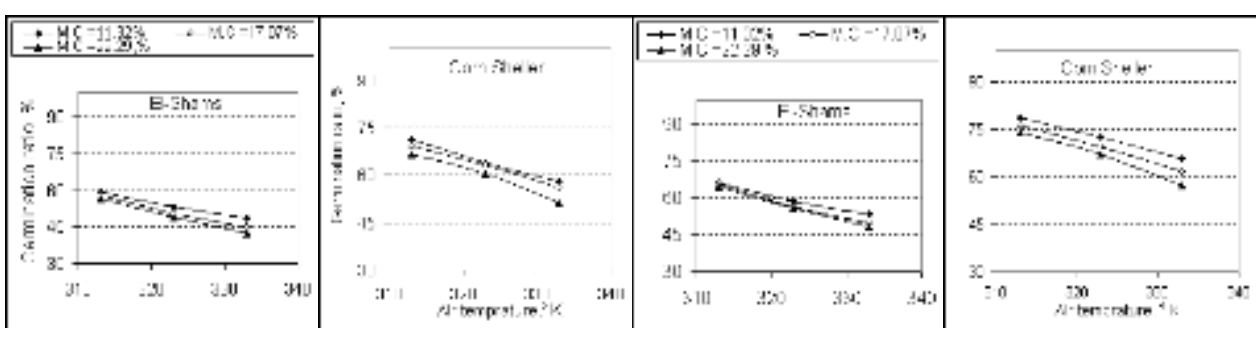

Figure(2): Effect of air temperature on germination ratio for El-Shams thresher and Corn Sheller at different moisture contents, feeding rate 2.5 and $5 \mathrm{~kg} / \mathrm{min}$ and drum speed of $400 \mathrm{rpm}$ 


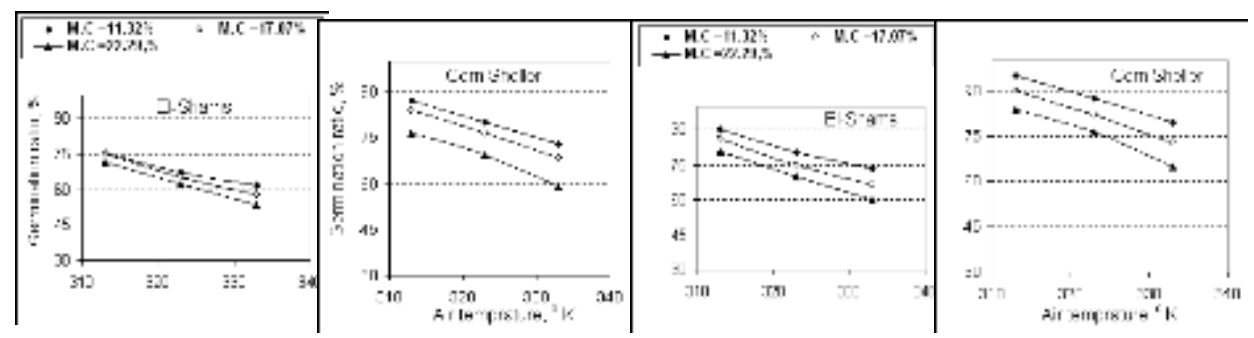

Figure (3): Effect of air temperature on germination ratio for El-Shams thresher and Corn Sheller at different moisture contents, 7.5 and $10 \mathrm{~kg} / \mathrm{min}$ feed rate and of $400 \mathrm{rpm}$ drum speed.

\section{CONCLUSION}

The highest values of the germination ratio were of about 95.1 and 90.03 $\%$ for the Corn Sheller and El- Shams threshing machines, respectively. at the minimum air temperature $40{ }^{\circ} \mathrm{C}(313 \mathrm{~K})$, highest level of feeding rate $(10 \mathrm{~kg} / \mathrm{min})$ and lowest level of moisture content $(11.32 \%)$. However the minimum values of the germination ratio were of about $62.35 \%$ and $54.14 \%$ for the Corn Sheller and El- Shams threshing machines, respectively, were obtained at the maximum airflow temperature of about $60{ }^{\circ} \mathrm{C}(333 \mathrm{~K})$, lowest level of feeding rate $2.5 \mathrm{~kg} / \mathrm{min}$ and a highest level of moisture content of $22.29 \%$ (w.b.)

\section{Recommendations}

The optimum condition for drying process are at air temperature of 333 ${ }^{\mathrm{o}} \mathrm{K}$ and sunflower heads moisture content of $17.07 \%$.

\section{REFERENCES}

Brooker, D. B.; F. W. Baker - Arkema and C. W. Hall (1978). Drying cereal grain. $2^{\mathrm{n} d}$ Edition. AVI publishing Co., Westport, Conn., INC., USA.

Grady K. K. (2004). Sunflower production, oilseed breeder and extension specialist SDSU plant Science department.

Harner (1987). Drying and Storing Sunflowers Cooperative Extension Service.

ISTA (1985). International rules for seed testing. Seed Sci. Technol.13 :299-335. 
Li, H. and R. V. Morey (1984). Thin-layer drying of yellow dent corn. Transactions of the ASAE: 581-585.

Li, H.; R. V. Morey and M. Afinrud (1987). Thin-layer drying rates of oilseed sunflower. Transactions of the ASAE, 30 (4): 1172-1175, 1180.

M A F (2004). Sunflower production and management.

Michael, A. M. and T. P. Ojha (1978). Principles of agricultural engineering, Volume 1, Farm power and machinery, Farm building and post - harvest technology. 873, East Park Road, Koral Bagh, New Delhi - 110005 .

Saskatchwan (1993). Early maturing short stature (EMSS) sunflower.

Warrick B. E. (2004). Sunflower production guide for West Central Texas. P: 1-15.

Yearbook of Agriculture (1990) F.A.O. Arab Agricultural Statistics التقريز الصادر عن قطاع الثئون الاقتصادية بوزارة الزراعة واستصلاح الأراضى عن موقف (بأف

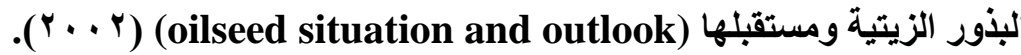

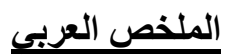

جودة تجفيف محصول عباد الشمس بعد عملية الدراس الميكانيكى د/ حمادة على الخطيب* د/ حسين سرور ** د/ محمد عبداللة خضير * م/ محمد سعد*

يعتبر محصول عباد الثنمس من أهم المحاصيل الزيتيـة على مستوى العـالم حيـث يعتبر ثناني

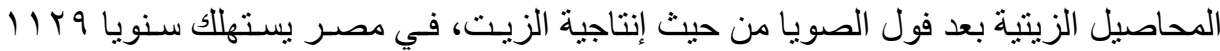

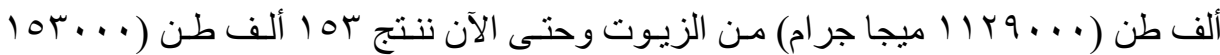
ميجا جر ام) فقط هذا يعنى أن إنتاجنا من الزيوت ئ يعادل

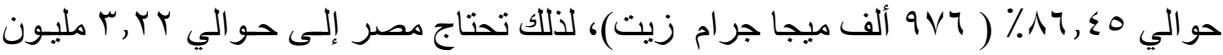

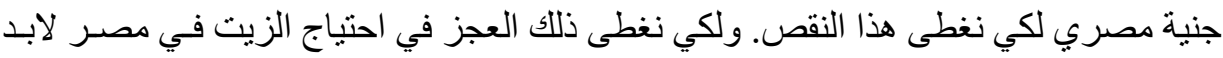

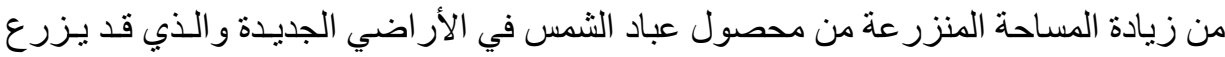

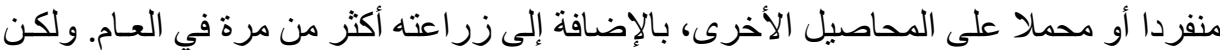

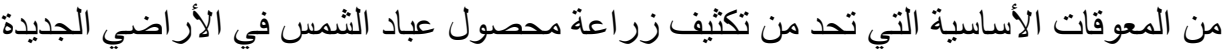

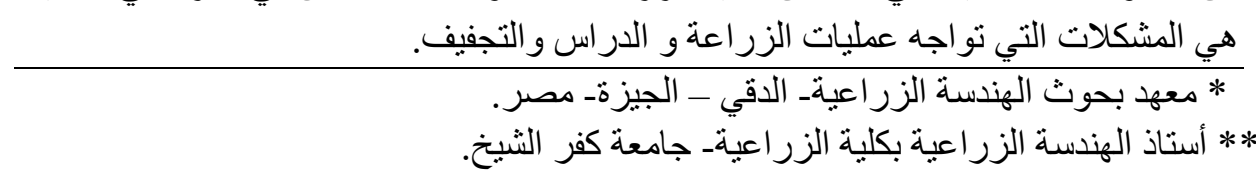




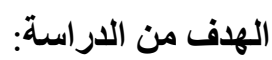

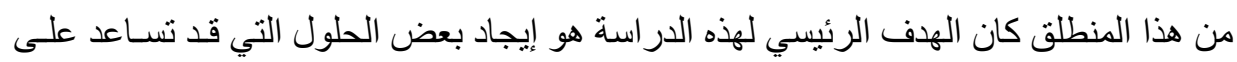

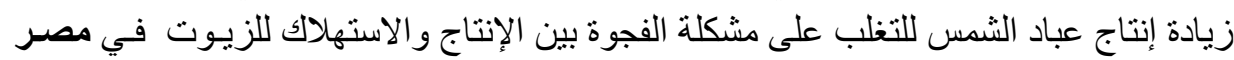

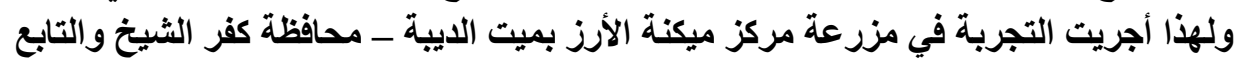

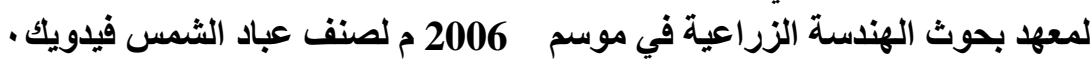
ولهذا اشتملت الدر اسة على مايلى:-

ا - تجفيف بذور عباد الثمس باستخدام درجات حرارة مختلفة لتقدير فو افد الحبوب أثنـاء تجفيفها بعد عملية الدر اس الميكانيكى.

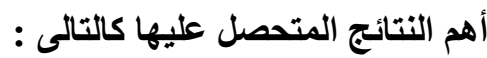

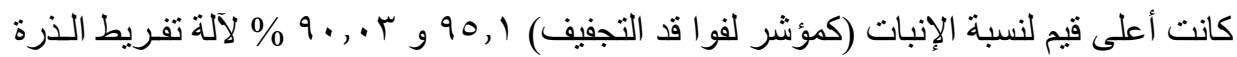

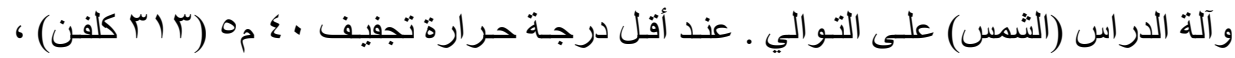

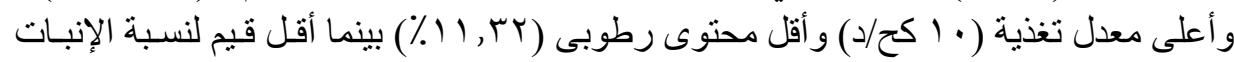

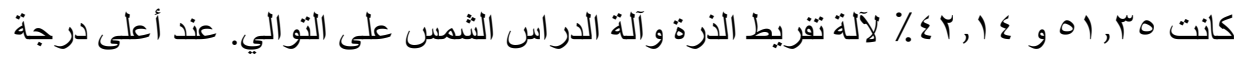

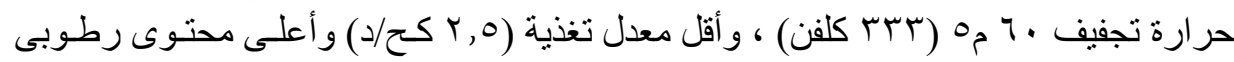
(\% (\%, rq)

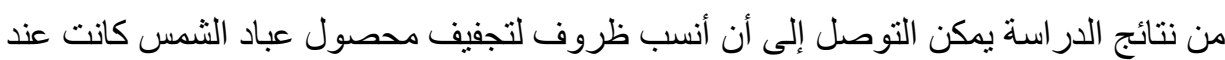

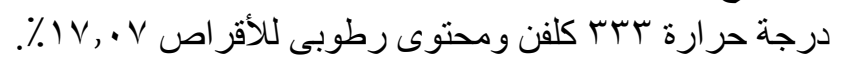

